Горбачев В. И.

(Веллингтон)

УДК 008

\title{
RESEARCHING SIMULATIONS OF THE PAST: HISTORICAL RE-ENACTMENT AS AN ACADEMIC DISCIPLINE
}

Историческая реконструкция проделала долгий путь от карнавалов и исторических шествий и празднеств, уходящих корнями в Средние века, через хобби военных постановок и любителей «живой истории» до научного экспериментально-археологического метода, а теперь и самостоятельной академической дисциилины, провозглашенной таковой в самом начале 2020 года. Предметом научных исследований исторические симуляиии - материальные (костюмы, снаряжение, жилища, физические объекты и артефакты) и нематериальные (значимые события, технологии, традиции, культы) являются уже около 40 лет. Академический интерес к теме растет все более активно и давно вышел за рамки практической или публичной истории, музеологии, наук о наследии, антропологии и философии, создав все предпосылки для выделения этого научного предмета в специальную дисииплину. В данной статье автор предпринимает попьтку проследить историографию исторической реконструкиии как науки, ответить на вопрос, что она собой представляет, каков её предмет изучения, методические принципы, понятийный аппарат, и какую роль она занимает в системе академических дисциплин. Последнее время историческая реконструкиия привлекает пристальное академическое внимание. Она принята в качестве технологии наследия и представляет собой значительную часть особой дисциилины в «исследованиях по реконструкции». Многие элементы живой истории были хорошо изучены, а ее потенциал для «конструктивности» был тщательно оченен. Тем не менее, многочисленные аспекты его потенщиала еще предстоит раскрыть. Обзор литературы также показывает, что исследования по реконструкиии могут принести пользу подходу управления бизнесом, использовать термины индустрии наследия, изучить влияние клиентского обслуживания и экономию опыта на согласованную аутентичность в целом.

Ключевые слова: историческая реконструкция, живая история, историческое моделирование, подлинность.

Historical re-enactment (HR) has come a long way. From carnivals and pageants originating in Medieval Times, through a hobby for battlefield performers and activities by costumed societies to a scientific method of experimental archaeology, and now HR has become a distinct academic discipline, proclaimed in early 2020. Historical simulations - tangible costumes and associated material culture, habitats, artefacts and intangible culture (staged events, replicated technologies, traditions and cults) - have been an object of academic research for about 40 years. The scholarly interest has been growing and exceeded the scope of its initial field of applied and public history, museum and heritage studies, philosophy and anthropology, to now form an academic framework of its own. In this article the author tries to analyse the literature of the field and describe HR as an academic discipline, its object of research, methodology and key terms, and the spectrum of studies it is engaged with. To sum up, HR attracts careful academic attention. It is accepted as a heritage technology and constitutes a significant part of a distinctive discipline in 're-enactment studies'. Many ele-ments of living history have been well explored, its potential for 'constructedness' or in Scott Magelssen term '3-D sandbox space' has been carefully evaluated. However, numerous aspects of its potential are still to be revealed. The literature review also indicates that re-enactment studies can benefit a business management approach, to employ heritage industry terms, to explore the im-pact of client service and the experience economy on negotiated authenticity and HR in general as well as material culture studies, and could also contribute much in the development of the notion of 'replica' as a key concept of HR. 
Keyterms: historical re-enactment, living history, historical simulation, authenticity.

DOI: $10.24888 / 2410-4205-2020-24-3-124-135$

$\mathrm{H}$ istorical re-enactment (HR) or living history is a wide repertoire of genres and practices that can replicate the material culture of the past and simulate actions, behaviours and historical events for present purposes. In recent decades, HR has been a topic of research for historians, anthropologists, philosophers and sociologists. As an experimental method, it has been widely used to test archaeological and socio-psychological hypotheses. Yet many academics dismiss 'living history' as an amateurish hobby that has nothing to do with 'real' history or heritage. However, the work of several researchers of the last two decades, as well as their predecessors at the end of the 20th century, culminated in the development of a distinct discipline of re-enactment studies as seen in the publication of a multi-authored book The Handbook of Re-enactment Studies, which shows an important turn in the perception of 'living history' by the academic world [8]. This new discipline validated the long struggle of public history practitioners in legitimising bodily experience and affective comprehension of the past as a vehicle for learning, understanding, interpreting, and constructing personal meanings of history and heritage. It became possible as a result of the constant research interest in the topic for several decades since the early 80s. Re-enactment studies encompasses more than 300 publications on historical simulations and imitating the past. They developed their interdisciplinary methodology at the confluence of history (including public history), heritage studies, archaeology, philosophy, sociology, anthropology, and cultural studies. The discipline also involves material culture, theatre and performance, leisure and recreation theories. That makes re-enactment studies a young and highly promising direction in academic thinking today.

The framework of HR research was nurtured within the confluence of both history and museum and heritage studies. It involves academic thinking about what history is and how it can represent the past and also how the past can be represented in museums. Traditionally in the literature heritage is considered as the conservation and popularisation of what is left from the previous populations in museum collections and in situ. The first researcher to broaden it out from this was Robin George Collingwood. In his canonical work The Idea of History he investigated the representation of the past and defined history as a re-enactment of the past experience [29]. That established two parallel perspectives on museum objects: as a part of or coming from the past and representing it. Although Collingwood was mostly focused on academic history, his conception provided the basis of many museum and heritage technologies in the following decades.

Another important milestone in the development of the paradigm of HR studies was set in Raphael Samuel's book Theatres of memory [93]. He closely investigated several key points about the nature of history, including its subdivision into academic and popular, social memory and staging of the past. Calling history "a mimetic art" he sees two parallel dimensions in the practice of history: "a documentary proof" in academics and different forms of representative exercises with "a gauge of authenticity" [93, p.434]. Since then 'authenticity' in heritage theory has gained a new quality, not only a mark of real historical artefacts but also a flexible tool to measure and evaluate the relevance (or representativeness) of the past and a highly disputable or negotiated term $[32,79,86]$. A shift from the idea of authenticity as a single canon of heritage was made towards the conception of a reference to anything what can illustrate the past.

Altogether ideas of negotiated representativeness and authentic experience constituted a significant part of the concept of new museology - a critical approach which led to a compound shift in perception of museums' authority, political and social role followed by changes in many aspects of museum practice $[32,72,84]$. HR studies comes alongside that reconception of museum theory and practice.

What is more significant for HR's academic framework is the topic of the public dissemination of historical knowledge and social issues surrounding it, including a debatable question of 
the accessibility of wider audiences to the findings of historical scholarship. In this respect public history is considered a rebellion against the institutional control of the production and distribution of knowledge about the past, and the power of museums to convey that authority [99]. It generated the dichotomy of two types of historical practice: authoritative "from above" (universities, academia, and museums adjoining them) and democratic "from below" (family and ethnical history, personal collections, local heritage pride events, etc.). It is argued that HR is a flexible construction which unites those two, using the results of academic researchers for the communal purposes of local societies, providing accessible engaging dissemination of historical (academically acquired) knowledge.

In this respect the model of HR production is as follows: past $=>$ history $=>$ re-enactment. i.e. history is merely a volume of our knowledge about past events and generations, which acts as a resource for historical simulations. It is based on the assumption that we cannot simulate what we don't know yet. So history comes first to learn things and form knowledge, and only then we have HR to illustrate and represent it. That also means that HR is denied in its epistemic quality, making it an academically informed popular practice.

But the new academic discipline develops another methodological tenet, where HR is a distinct interpretation strategy, like history itself. The past can be interpreted and written as a book, it can be produced as a documentary, the same way it can be pictured and experienced as a simulation, which makes HR a form of interpretation [62]. This theory comes alongside the recent 'material turn' in history and humanities. A New Zealand historian and museum practitioner Bronwyn Labrum investigated its influence on historiographical practice. "It is a way to think about objects and materiality as experiences frequently captured only clumsily in writing and language, the conventional tools of the historian", Labrum argues [68, p. 806].

This assumption can be easily applied to HR. So, if history is a practice of contextualisation of the past, HR in its turn is a means to visualise and experience the past through material culture and imitations. But the keystone of that tenet to establish HR as a historiographical practice lies in its evidentiary quality [8]. Experimental archaeology has been developing the methodology to practically test this hypothesis by a controllable experiment [25]. The same technique is often used in judicial practice to verify the feasibility of the accused to commit their crime in certain circumstances. In both cases the independent adjudicator is the principles of physics assumed unchangeable for any time and place. If something is possible as a controllable experiment, it could have taken place in the past. But experimental archaeology also reveals many technical details and peculiarities which help us learn new things about the past, making HR a very efficient historiographical practice. Thus rigorous academically-informed simulations enable us to be eye witnesses of history and provide a means for us to explore the past and spread knowledge. That game-changing nature of HR "demands a rigorous reconception of what we mean by the past, and by its reenactment" $[8$, p. 6].

HR studies has developed a body of literature of more than 300 publications. The earliest prominent researcher was Jay Anderson who was one of the first to introduce 'living history' as a study object, a term and a phenomenon of public history in the USA $[11,12,13,14]$. He was followed by Richard Handler who investigated authenticity and realism as key notions in HR [51, $52,53,54,44]$. The book Confederates in the attic which became very popular the United States analyses Civil war battle re-enactments as "unfinished" business, demonstrating HR as a way to deal with difficult histories [58]. In the 90s there were also four theses on the topic studying HR in Canada [41], re-enactors' communities [42], costumes and authenticity [71] and AfricanAmerican history at Colonial Williamsburg museum [70]. A contribution to the methodological techniques of living history was made by Stacy Flora Roth [92]. All the named researches took part in the North America. A chapter in Raphael Samuel's Theatres of Memory provides a deep analyses of living history in Britain [93].

Another academic impulse at this time in the 21 st century was spawned by the reenactment project of James Cook's first voyage to the South Pacific. Four scholars - Vanessa 
Agnew, Alexander Cook, Iain McCalman and Jonathan Lamb - took part in the experiment and shared their experience in a series of articles with ambiguous appraisal of the project and the whole approach $[2,3,5,30,31,82]$. But a few years later the results were rethought and revised $[4,69,83]$. Now these four scholars are among the most prominent researchers in the field. They edit and publish a series "Reenactment History". Another common place to find publications on HR is Rethinking History: The Journal of Theory and Practice. It allows academics to experiment with new ways of presenting and interpreting history [24, 46, 91, 40, 96, 4].

Since the first decade of the $21^{\text {st }}$ century an outburst of academic interest in HR has been observed. Some researchers gave descriptive general analyses of that heritage practice. Stephan Gapps' $\mathrm{PhD}$ thesis was devoted to the development of the movement in the $20^{\text {th }}$ century, he also touched on the questions of performance and bodily experience in HR and he studies the work of living history museums [45]. Jonathan Lamb provided a penetrating analysis of the form of people's relations with the past from a philosophical perspective[69]. An interesting approach is taken in Daugbjerg 2015 with the focus on HR as material human "patchworking" of historical reality and the idea of "unfinishedness" as a motivation for it. De Groot looked at living history through the lens of global consumerism and commodification of history and culture (de Groot 2016). Another general description of HR can be found in Dean 2019. He gives a short review of the history of the movement, of how it works and of its specific components. In her PhD thesis Jaime Wright provides a holistic analysis of simulated and experienced history, investigating different aspects of HR [102].

There are researchers who went even further and developed their own theoretical and practical conceptions of the basis of HR and living history simulation, such as Cornelius Holtorf who looked at the wider topic, including the future as a "destination" in re-enactment, calling his approach "Time Travel" [56, 57, 90]. His funded project in Lund University Sweden culminated in an edited volume The Archaeology of Time Travel [90]. It encompasses different topics, among them are 3D historical visualisations, cinematography, social and educational aspects.

Another interesting approach is taken by Vanessa Agnew and Jonathan Lamb in Settler and Creole Reenactment [1]. In this volume HR is considered in the context of the post-colonial world and its European and Indigenous Societies. The book also contains some of the rarest articles on living history in remote Australia, Aotearoa New Zealand and Oceania.

There is a significant amount of publications studying different elements of living history taken both specifically in an HR context and in a broader setting. The key concept in HR is 'authenticity'. It is based on the above-mentioned post-modernist perception of representativeness adopted in museum and heritage practice [55]. The idea of copying the past was developed by Jean Baudrillard. He introduced the notions of simulacra - the copy of things which do not exist anymore, and simulation which refers to the imitation of processes and actions which took place in the past [103].

Every researcher of living history cannot avoid the matter of authenticity without which the understanding of HR is entirely impossible. The discourse consists of several general bodies of knowledge. The first is how re-enactors themselves perceive authenticity. It can be summarised as an imperative, an ultimate goal for HR practitioners [91], the ne plus ultra of the reconstructions [8], or the measure of the quality of their work [24]. It is achieved by some re-enactors as the result of their constant and intensive studying of academic history, and developing their craftsmen skills $[46,71]$.

Another approach evaluates the authenticity in HR as an interpretation strategy in museums. Erick Gable and Richard Handler analysed the work of Colonial Williamsburg in the early 90 s to describe the functionality of historical fidelity as "credibility armour" i.e. a way to protect the reputation of the institution against critiques [44]. Jeanette Atkinson analysed the cooperation between museums and 'costumes societies' and the type of authenticity it can produce $[15,16,17,18]$. 
In the process of academic analyses another entity of authenticity was revealed which is important to understand for its crucial role in HR. First it was mentioned that re-enactors selectively use history to arrange their events and freely manipulate it [91, 50], then that observation was developed into an idea that negotiated authenticity provides a unique opportunity for 'constructedness' in living history [8], i.e. the past becomes a flexible and plastic material in the hands of HR practitioners [69]. In the same way Richard Handler and William Saxton analysed the material fidelity of replicas and reconstructions, used as props for storytelling and connected it with the conception of Heideggerian narrative authenticity. It resulted in the understanding of HR as "storied/emplotted" experience of the past [54].

In re-enactment studies 'authenticity' has gained a new meaning. It makes simulation possible indicating its historical veracity. Thus, authenticity is a key notion of HR which both provides the academically informed strict constraints of historical fidelity and plastic freedom to construct the past needed for certain present purposes. So metaphorically speaking, authenticity is that skeleton key to open the door to the past, intensively sought after by both re-enactors trying to practically achieve it and researchers in re-enactment studies trying to understand the inner mechanism in HR.

The second key in analysing HR is 'experience'. In this sense the theory is usually based on the ideas of Victor Turner and Edward Bruner provided in The Anthropology of Experience [104]. In living history re-enactors use their bodies and corporeal experience to feel the past. They call it a period rush. That holistic, haptic sensations shorten the distance between the present and the experienced past as close as possible to get the feeling "what it must have been like" [34]. The idea of immediacy of experience in historical re-enactment is analysed by Anja Shcwarz [8]. The understanding of bodily nature of communication in HR provided the ground for researchers to develop the conception of embodiment, as the identification of a modern person's body and sensation with those of a person from the past real or imagined $[62,8]$. One of the qualities of HR is the ability to provide authentic experience as another dimension to communicate with the past [33].

One of the most important outcomes of experience in HR is learning. This living history element has been investigated by many researchers $[48,28,63,97,61,62,8]$. The main principle of education in HR is based on the idea of learning through doing [28], when bodies become research tools [8]. An interesting perception of material culture in HR as didactics for dissemination of historical knowledge is given in Svendsen 2010. It is also taken in the conceptualisation of $\mathrm{HR}$ as a well-known tool in museum education, the idea of 'edutainment' [28], i.e. the combination of learning and interactive entertainment. According to Jones 2014, HR through learning can contribute to historical consciousness. Most of the authors agree on the idea that only academically-informed historical simulation can provide powerful 'edutainment'. If it is not authentic, it is not learning, which of course proves the efficiency of the HR recipe of two components: authenticity and experience.

Promoting his conception of living history as simulations and terming it 'simmings' Scott Magelssen gives the most exhausting definition of experience in HR:

Simmings can be profound and generative in their ability to witness another's experience through physical embodiment and even discomfort. They promise three-dimensional sandbox spaces in which to experiment and play, allowing for details, contingencies, and variables that cannot be imagined on paper. Simmings identify and reify a community's makeup and its values, as well as marking and protecting against the threats to those values. They can help us rehearse for a better tomorrow, and to invoke it by committing an imagined futurity to the kinesthetic memory of our muscles, nerves, and bones. [78, p. 183].

An important part of investigations on experience in HR is its affective quality based on establishing personal emotional connections with the past. Vanessa Agnew considers living history indicative of the recent 'affective turn' in the historical sciences, by which she means the collapsing of the emphasis on events, structures and processes in historiography, replaced with daily life, in- 
dividual experience and personal bonds as key foci of much contemporary historical research[4]. The author traces HR to that affective turn in history. An important contribution is made by Mark Franko and his co-authors. In the context of dance and choreography, they explore how representation as the main conception behind HR is transformed into historical experience and an affective relation to the past in the present [43]. Promoting the same idea, the editors of a 2010 collection of articles on HR, called their volume Historical Reenactment: From realism to the affective turn [81]. An interesting observation made by Brad West contributes to the understanding of the affective quality of HR experience. Analysing Civil War simulations in the USA, he describes reenactors' 'affective authority' as the right to speak for their historical prototypes, real participants of the events of 1861-1865 on the base of the experience they had in re-enacted events[100]. In other words, they re-enacted it, they felt what it was like, and now they have the authority to truly 'speak' about the war. That signals a very strong connection with the past, which HR experience can provide for 'time travellers'.

The inner mechanism within HR of authentic experience is driven by reproduced material culture. Bronwyn article? In HR replicas navigate the experience and are guides in time travel. Material culture has a special emphasis in this research. The role of materiality in providing HR experience is analysed by Mads Daugbjerg [33, 34,35]. In the Handbook of Reenactment Studies Stefanie Samida argues that history in HR is mediated through things [8]. She emphasises that the very physicality of the past is produced by replicas. To sum up, authors agree on the role replicated material culture in HR plays as the gateway to the experience of the past. Supporting the transformative aspect of material culture, David Kobialka contributes to the topic by exploring the outfitting and associated physical objects of modern Vikings and the replica production market in Northern Europe[67]. Mark Auslander discusses the quality of 'props' that replicas can gain and their ability to substitute for historical artefacts[19].

HR is a system of interconnected and interdependent elements. When we speak about the use of body and mind in living history, we inevitably deal with theatre. HR as embodiment of the past has a performative nature[60]. It has become popular in re-enactment literature to analyse historical simulations and historically informed performances from a theatre studies point of view, since Megan Mateer's thesis on how performance is used to examine the past in living history museums, historical dramas, experiential archaeology projects and TV productions [80]. Scott Magelssen employed that approach to explore HR museums in the USA [76]. Playful performativity as a key quality of HR and staging as a key technology to present living history have been considered to provide space for (1) learning, entertaining and making historical knowledge a popular format [62, 81, 80] (2) for social memory practice [95, 62] and even (3) historiographic operations [76]. Basing her thought on Colingwood's idea of history as re-enactment, Katherine Johnson develops it into the idea that history itself is the performance of the past in words, images and actions. She argues that in post-modern historical practice HR has the performative capacity to 'function historiographically'[62].

Theatre, performance and embodiment seem to be an integral part of HR, a dominant interpretation technology, allowing (re-en)actors to represent and speak for their historical prototypes. "First-person character interpretation," Magelssen argues, "in which costumed staff speak in the first-person present tense when informing visitors about the lives and times they portray in the museum's environment, continues to be the most celebrated form of historiographic performance at living history sites" [75]. It challenges the traditional third-person interpretation which is the idea of speaking 'about' them and telling their story. There is some debate on the effectiveness of both technologies. David Allison and Stacy Roth consider it the most efficient technology in the context of classical living history museums in the USA [9, 92], while an analysis made by a group of Australian researchers indicated that visitors at a recreated 1850s gold-rush heritage tourism site liked third-person interpretation better [98]. Investigating both forms of interpretation strategies in American heritage sites, Scott Magelssen compared them with second-person costumed performance, which is more participatory, engaging visitors to take historical roles them- 
selves [75]. Another important contribution is made by Martine Teunissen, who explored living history interpretive programs and the role of theatre technologies in HR interpretation in general [105].

In the theatre world, historically-informed performances encounter the same difficulties in staging sensitive and delicate topics. They take special care and attention, that's why there is a number of works devoted to traumatic events of war and genocide [8], slavery and abolition[81], racism and troubled ethnic histories [64, 70, 19], and difficult pasts [66].

The popular, spectacular, performative, engaging and ludic nature of HR makes it a commercially sustainable form of heritage. This important feature of living history is being explored in academia. Re-enactment as a part of the tourism industry is investigated in Halewood and Kannam 2001 [49]. They looked at the ties between authenticity and commodification through the example of Viking heritage markets. They conclude that commodification is a key factor in negotiated authenticity, because being a commodity constrains a heritage product. The difficulties of reconciling cultural activity with business is the key focus of a Michal Pawleta's article on the commercialisation of the past [88]. The work is relevant because the author provides a broad discussion about positive and negative aspects of HR as the commodification of archaeology, and commercially positive approach is characteristic of the work I do.

HR is often considered to be an interpretative strategy in history which means that it has a narrative nature. Like history itself it is an artificial construct, but it is an important feature to research. Unfortunately, there is not much literature on the issue. The most valuable contribution was done by Richard Handler and William Saxton as early as 1988. Basing their work on Heidegger's perception of authenticity they conclude that in HR "authentic life is a storied or emplotted life". The literal reading of authoritative historical narratives enables living historians to have their real authentic experience and to install their reenactments into history [54]. In 2006 Megan Mateer's thesis she explored the peculiarities of how historical narrative is constructed in HR, which resulted in the conclusion of interpretative instrumentality HR has as a narrative tool [80]. It can be biased, politised, sanitised. Finally, Inke Arns, a contributor to The Handbook of Reenactment Studies, positioned history as a narrative between the past and HR[8]. In that situation, on one hand history as a narrative separates HR from the past and distances re-enactors from their illusory ne plus ultra of total authenticity, but on the other hand, from the narrative point of view, HR has that illustrative and representative story-telling capacity which completely accompanies the drive to community-building, to tell the story of the place.

Narrative and constructedness as features of HR provide an opportunity for identitybuilding and meaning making. It is evaluated in some research on different levels: indigenous Pacific identity through voyage reenactments [94], national American identity through Civil War commemorations [10], regional Scandinavian identity through rune stone carving [89], local community cultural identity through living history events [26]. The authors also emphasise the role of living history festivals in enhancement of community pride and maintaining cultural identity. This literature review shows that HR is widely accepted as a means to construct identity, which is an important part of community-building. The role living history can play in social cohesion is considered by Wendy Erisman. In her thesis she explored two popular and significant re-enactment societies and how that hobby helped them build their communities [42]. In this way she demonstrated how HR can contribute to social coherence in the context of re-enactors themselves. Ebbe Westergen studied the experience of 'Bridging ages', an international organisation focused on the use of history for the benefit of local communities [90]. Analysing the results of their practice in South Africa and Serbia in the context of the Time Travel conception (based on HR) he concludes that participatory engagement with the past to share and celebrate local history and heritage works towards better social cohesion and community building.

A very special place in the literature on HR is taken by $\mathrm{P}$ Wenzel Geissler and Ann $\mathrm{H}$ Kelly's research. They examined a scientific station located in Tanzania as a potential heritage site and as a resource for re-enactment. A unique study in its own way in terms of the methodo- 
logical potential of a technology and a place to simulate academic work and life and botanic, zoological and medical research in the tropics, it evaluates living history and its power to narrate scientific progress [106].

To sum up, HR attracts careful academic attention. It is accepted as a heritage technology and constitutes a significant part of a distinctive discipline in 're-enactment studies'. Many elements of living history have been well explored, its potential for 'constructedness' or in Scott Magelssen term '3-D sandbox space' has been carefully evaluated. However, numerous aspects of its potential are still to be revealed. The literature review also indicates that re-enactment studies can benefit a business management approach, to employ heritage industry terms, to explore the impact of client service and the experience economy [107, 108] on negotiated authenticity and HR in general as well as material culture studies, and could also contribute much in the development of the notion of 'replica' as a key concept of HR.

The appearance of HR and its theory can be considered a phenomenon typical of postmodernism. In her article "A Blurring of the Boundaries" Elaine Heumann Gurian notes that "as we no longer produce much of the unique thing, we may be becoming much more comfortable with the idea and use of reproductions and copies" [32, p. 83]. Nowadays simulations have become a new tool of historical epistemology and heritage communication.

\section{Список литературы}

1. Agnew V., Lamb J. Settler and Creole Reenactment. Palgrave Macmillan, 2010. 272 p.

2. Agnew V. What Can Reenactment Tell Us about the Past? // Criticism. 2004. № 46 (3). Pp. 327-339.

3. Agnew V. Introduction: What Is Reenactment? // Criticism. 2004. № 46 (3). Pp. $327-$ 339.

4. Agnew V. History's affective turn: Historical reenactment and its work in the present // Rethinking History. 2007. № 11 (3): Reenactment.

5. Agnew V. History's Pure Serene: On Reenacting Cook's First Voyage. Staging the Past: Themed Environments in Transcultural Perspectives. Bielefeld: Transkript. 2007.

6. Agnew V. Reenacting the Stone Age: Journeying Back in Time Through the Uckermark and Western Pomerania // A Companion to Public History (ed. D. M. Dean), Hoboken, New Jersey: John Wiley and Sons, 2007. Pp. 365-375.

7. Agnew V. Songs of Flight: War and Genocide Reenactment on the Refugee Route // Performing Commemoration: Musical Reenactment and the Politics of Trauma (eds. A. Fauser and M. A. Figueroa), Ann Arbor, University of Michigan Press, 2019. Pp. 170-199.

8. Agnew V., Lamb J., Tomann J. The Routledge Handbook of Reenactment Studies. Key Terms in the Field. Taylor and Francis, 2019. 232 p.

9. Allison D. Living History: Effective Costumed Interpretation and Enactment at Museums and Historic Sites (American Association for State and Local History). Lanham, MD: Rowman \& Littlefield, 2016. 122 p.

10. Amster, M. H. A Pilgrimage to the Past: Civil War Reenactors in Gettysburg // Reflecting on America: Anthropological Views of U.S. Culture (eds. Boston, Pearson/Allen and Bacon). New York: Routledge, 2008. Pp. 15-27.

11. Anderson, J. Living History: Simulating Everyday Life in Living Museums // American Quarterly. 1982. № 34 (3). Pp. 290-306.

12. Anderson J. (ed.) A Living History Reader: Museums, Nashville, American Association for State and Local History, 1991.

13. Anderson J. Time Machines: The World of Living History. Nashville: American for State and Local History. 1984. 260 p.

14. Anderson J. The Living History Sourcebook. Nashville: American Association for State and Local History, 1995. 217 p. 
15. Atkinson J. Engagement and Performance: Created Identities in Steampunk, Cosplay and Re-enactment. The Cultural Moment in Tourism, Abingdon: Routledge, 2012. 18 p.

16. Atkinson J. Steampunk, Bradford Industrial Museum // Museum Worlds: Advances in Research. 2013. № 1. Pp. 206-212.

17. Atkinson J. Steampunk's Legacy: Collecting and Exhibiting the Future of Yesterday. Steaming into a Victorian future: a steampunk anthology, Lanham, Md.: Scarecrow Press, 2013. 360 p.

18. Atkinson J. Steampunking heritage: how Steampunk artists reinterpret museum collections. A Museum Studies Approach to Heritage, 2018. 902 p.

19. Auslander M. J. Touching the Past: Materializing Time in Traumatic «Living History» Reenactments // Signs and Society. 2013. № 1 (1). Pp. 161-183.

20. Bielo J. Replication as Religious Practice, Temporality as Religious Problem // History and Anthropology. 2016. №. 28 (2). Pp. 131-148.

21. Blackson R. Once More ... with Feeling: Reenactment in Contemporary Art and Culture // Art Journal. 2007. № 66 (1). Pp. 28-40.

22. Blanco-Fernández Y., Nores M.L., Pazos-Arias J.J., Gil-Solla A., Cabrer M.R. \& Duque, J.G. REENACT: A step forward in immersive learning about Human History by augmented reality, role playing and social networking // Expert Syst. 2014. Appl. № 41. Pp. 4811-4828.

23. Boyd M. C. Performance Simulacra: Reenactment as (Re)authoring // Theory Now 2007. http://www.theorynow.blogspot.com/2007/05/performance-simulacra-reenactment-as.html

24. Brcedder Anne, Esmark Kim, Kruse Tove, Nielsen Carsten Tage \& Warring Anette. Doing pasts: authenticity from the reenactors’ perspective // Rethinking History. 2017. № 21 (2: Authenticity). Pp. 171-192.

25. Busuttil C. (2013). Experimental Archaeology // Malta Archaeological Review. № 2008-2009. Pp. 60-66.

26. Carnegie E., Mccabe S. Re-enactment Events and Tourism: Meaning, Authenticity and Identity // Current Issues in Tourism. 2008. № 11 (4). № 349-368.

27. Caronia A., Janša J., Quaranta D. RE:akt! Reconstruction, Re-enactment, Reporting, Brescia // Link Editions. 2009. Pp. 7-21.

28. Coles J., Armstrong P. Living history: learning through re-enactment. 2008. 411 p.

29. Collingwood R. G. The Idea of History. Oxford: Clarendon Press, 1946. 339 p.

30. Cook A. The use and abuse of historical reenactment: thoughts on recent trends in public history // Criticism. 2004. № 46 (3). Pp. 487-496.

31. Cook A. Sailing on The Ship: Re-enactment and the Quest for Popular History // History Workshop Journal. 2004. № 57. Pp. 247-255.

32. Corsane G. Heritage, Museums and Galleries: An Introductory Reader. London, UK: Routledge. 2005. 392 p.

33. Daugbjerg $M$. Patchworking the past: materiality, touch and the assembling of 'experience' in American Civil War re-enactment // International Journal of Heritage Studies. 2014. № 20 (7-8). Pp. 724-741,

34. Daugbjerg M. 'As Real as It Gets': Vicarious Experience and the Power of Things in Historical Re-Enactment // Doing History: Performative Praktiken in der Geschichtskultur (eds. S. Willner, G. Koch and S. Samida), Münster, Waxmann. 2016. Pp. 151-171.

35. Daugbjerg M., Rivka S. E., Britta T. K. Re-enacting the past: vivifying heritage 'again' // International Journal of Heritage Studies. 2014. № 20 (7-8). Pp. 681-687.

36. Daugbjerg M., Rivka S. E., Britta T. K. Re-Enacting the Past. Heritage, materiality and performance. London: Routledge, 2015. 152 p.

37. Daugbjerg M. Borders of Belonging: Experiencing History, War and Nation at a Danish Heritage Site. 2014. № 5: Museums and Collections. New York: Berghahn, 202 p.

38. de Groot J. Affect and empathy: re-enactment and performance as/in history // Rethinking History. 2011. № 15 (4). Pp. 587-599. 
39. de Groot J. Consuming History: Historians and Heritage in Contemporary Popular Culture. New York: Routledge, 2016. 316 p.

40. During S. Mimic toil: Eighteenth-century preconditions for the modern historical reenactment // Rethinking History. 2007. № 11 (3: Reenactment). Pp. 31-57.

41. Ellerman P. An Examination of the State of Historical Re-Enactments in Canada. M.A. Thesis. Trent University.

42. Erisman, Wendy Elizabeth. Forward into the Past: The Poetics and Politics of Community in Two Historical Re-Creation Groups. PhD diss., University of Texas. 1998

43. Franko, M. (ed.) The Oxford Handbook of Dance and Reenactment, Oxford, Oxford University Press. 2018

44. Gable, Eric, and Handler, Richard. After Authenticity at an American Heritage Site // American Anthropologist, New Series, 1996. Vol. 98, No. 3. pp. 568-578.

45. Gapps, S. Performing the Past: A Cultural History of Historical Reenactments, PhD Thesis, University of Technology, Sydney, 2002.

46. Gapps, S. Mobile monuments: a view of historical reenactment and authenticity from inside the costume cupboard of history // Rethinking History. Vol. 11. № 3. 2007.

47. Gapps, S. Museums of the Living Dead: Performance, Body and Memory at Living History Museums // Journal of Curatorial Studies, 2018. vol. 7, no. 2. pp. 248-270.

48. Goodacre, B., Baldwin, G. Living the Past: Reconstruction, Recreation, Reenactment and Education at Museums and Heritage Sites. London: Middlesex University Press. 2002.

49. Halewood, C., Kannam, $K$. Viking Heritage Tourism: Authenticity and Commoditisation // Annals of Tourism Research 28(3). 2001. Pp. 565-580.

50. Hall, G. Selective Authenticity: Civil War Reenactors and Credible Reenactments // Journal of Historical Sociology. 2016. vol. 29. no. 3. pp. 413-435.

51. Handler, R. Authenticity // Anthropology Today. 1986. vol. 2. no. 1. pp. 2-4.

52. Handler, $R$. Overpowered by Realism: Living History and the Simulation of the Past // Journal of American Folklore. 1987. vol. 100. pp. 337-341.

53. Handler, R. and Gable, E. The New History in an Old Museum: Creating the Past at Colonial Williamsburg, Durham, Duke University Press. 1997

54. Handler, R., Saxton W. Dyssimulation: Reflexivity, Narrative, and the Quest for Authenticity in "Living History" // Cultural Anthropology. 1988. 3(3). Pp. 242-260.

55. Hart, L. Authentic Recreation: Living History and Leisure // Museum and Society. 2007. vol. 5. no. 2. pp. 103-124.

56. Holtorf, C. On the Possibility of Time Travel // Lund Archaeological Review. 2010 15- 16. Pp. 31-41.

57. Holtorf, $C$. Time Travellers' Tools of the Trade: Some Trends at Lejre // International Journal of Heritage Studies. 2013. Pp. 1-15.

58. Horwitz, T. Confederates in the Attic. Dispatches from the Unfinished Civil War, New York, Vintage. 1998

59. Hunt $S$. Acting the part: 'living history' as a serious leisure pursuit // Leisure Studies. 2004. 23:4. Pp. 387-403.

60. Johnson, K. Performing Pasts for Present Purposes: Reenactment as Embodied, Performed History // History, Memory, Performance (eds. D. Dean, Y. Meerzon and K. Prince), Hampshire and New York, Palgrave Macmillan. 2014. pp. 36-52.

61. Johnson, K. Rethinking (Re)doing: Historical Re-enactment and/as Historiography // Rethinking History. 2015. vol. 19. no. 2. pp. 193-206.

62. Johnson, K. Re-enactment's (Em)bodying of History, PhD Dissertation, University of Sydney. 2016.

63. Jones $C$. You could See it [the Past] in your Mind": What Impact Might Living History Performance Have on the Historical Consciousness of Young People? // EXARC Journal 2014. Vol.1 https://exarc.net/ark:/88735/10141 
64. Jordan, B. M. 'We Stand on the Same Battlefield': The Gettysburg Centenary and the Shadow of Race // Pennsylvania Magazine of History and Biography. 2011. vol. CXXXV. no. 4. pp. 481-511.

65. Kalshoven, Petra Tjitske. Plays on "The Indian": Knowledge, Desire, and Play // Indianist Reenactment. Berghahn Books. Incorporated. 2012.

66. Kelly, V. Ghosts of the Past: Breaker Morant and Re-enactment // History Australia 2009. vol. 6. no. 1. pp. 08.1-08.14.

67. Kobiatka, D. The Mask(s) and Transformers of Historical Re-Enactment: Material Culture and Contemporary Vikings // Current Swedish Archaeology. 2013. 21. pp. 141-161.

68. Labrum, Bronwyn. Material Histories in Australia and New Zealand: Interweaving Distinct Material and Social Domains // History Compass. 2010. no. 8. pp. 805-16.

69. Lamb, Jonathan. Historical Re-enactment, Extremity, and Passion // The Eighteenth Century. 2008. Vol. 49. No. 3. pp. 239-250.

70. Lawson, A. L. "The Other Half": Making African-American History at Colonial Williamsburg, unpublished $\mathrm{PhD}$ thesis, University of Virginia. 1995.

71. Lovell B. The costumes of the past: the first Virginia and the authenticity of historical reenacting. M.A. thesis. The College of William and Mary in Virginia. 1992.

72. Macdonald, S. A Companion to Museum Studies. John Wiley \& Sons. 2011.

73. Macdonald, S. Memorylands. Heritage and Identity in Europe Today, London, Routledge. 2013.

74. Magelssen, S. Living History Museums and the Construction of the Real through Performance // Theatre Survey. 2004. vol. 45. no. 1. pp. 61-74.

75. Magelssen, S. Making History in the Second Person: Post-Touristic Considerations for Living Historical // Theatre Journal. 2006. Vol. 58. No. 2. pp. 291-312.

76. Magelssen, S. Undoing History-Authenticity, Tourism, and the Precise and Vulgar Continuum: The Staging of the Past Through Performance and Display as Historiographic Operation at Living History Museums in the United States. PhD diss., University of Minnesota. 2007.

77. Magelssen, S. Living History Museums: Undoing History Through Performance. Lanham (MD): Scarecrow Press. 2007.

78. Magelssen, S. Simming. Participatory Performance and the Making of Meaning. University of Michigan Press. 2014.

79. Marstine, J. New Museum Theory and Practice: An Introduction. Oxford: Blackwell Publishing. 2006.

80. Mateer Megan. Living history as performance: an analysis of the manner in which historical narrative is developed through performance. $\mathrm{PhD}$ diss., Bowling Green State University. 2006.

81. McCalman, Iain and Pickering, Paul A. Historical Reenactment. From Realism to the Affective Turn. Springer. 2010.

82. McCalman, Iain. The Little Ship of Horrors: Reenacting Extreme History. Criticism Wayne State University Press. 2004.

83. McCalman, Iain. Lost in the Labyrinth: Reenacting and rethinking James Cook's Endeavour voyage through the Great Barrier Reef. The Vaughan Evans Memorial Lecture. 2011.

84. McCarthy, Conal. Museum Practice: The International Handbooks of Museum Studies. Wiley-Blackwell. 2015.

85. Meder, Tatjana, Seipelt, Jana and Slanitz, Sabrina. Living History as an Instrument for Historical and Cultural Exchange in German Archaeological Open-Air Museums: an Online Survey Defines Present Status. 2016. exarc.net/issue-2016-4/int/living-history-instrumenthistorical-and-cultural-exchange-germanarchaeological-open-air-museums

86. Melotti, M. The Plastic Venuses: Archaeological Tourism in Post-modern Society. Newcastle upon Tyne: Cambridge Scholars. 2011.

87. Palmié S., Stewart C. The Varieties of Historical Experience. Routledge. 2019. 
88. Pawleta M. "The past industry": selected aspects of the commercialisation of the past and products of archaeological knowledge in contemporary Poland // Sprawozdania Archeologiczne. 63.9-54. 2011.

89. Petersson, $B$. Travels to identity: Viking rune carvers of today // Lund Archaeological Review, 15: 71-86. 2009.

90. Petersson, Bodil and Holtorf, Cornelius. The Archaeology of Time Travel. Experiencing the Past in the 21st century. Archaeopress, Oxford. 2017.

91. Radtchenko, Daria. Simulating the past: Reenactment and the quest for truth in Russia // Rethinking History. Vol. 10. 1. 2006.

92. Roth, S. F. Past into Present: Effective Techniques for First-Person Historical Interpretation. Chapel Hill. University of North Carolina Press. 1998.

93. Samuel Raphael. Theatres of Memory: Volume 1: Past and Present in Contemporary Culture, Vergo. 1994.

94. Scanlan Reimagining National Identity through Reenactment in the Pacific and Australia // Wasafiri. 2017. 32:1. Pp. 60-67.

95. Schneider, R. Performing Remains: Art and War in Times of Theatrical Reenactment. London/New York: Routledge. 2011.

96. Schwarz, Anja. 'Not this year!' reenacting contested pasts aboard the ship // Rethinking History. 2007. Volume 11, Issue 3: Reenactment. Pp. 427-446.

97. Svendsen, A. R. Learning Through Experience. A Study of Visitors' Experiences and Learning at Foteviken Archaeological Open-air Museum // EuroREA. 2010. 7. Pp. 51-54.

98. Van Dijk Pieter A., Smith Liam D. G., Weiler, Betty. To Re-Enact or Not to Re-Enact? Investigating the Impacts of First- and Third-Person Interpretation at a Heritage Tourism Site // Visitor Studies. 2012. 15:1. Pp. 48-61.

99. Walsh, Kevin. The Representation of the Past: Museums and Heritage in the PostModern World. London: Routledge. 1992.

100.West, Brad. Historical re-enacting and affective authority: performing the American Civil War // Annals of Leisure Research. 2014. 17:2. Pp. 161-179.

101.Willner, Sarah, Samida, Stefanie, Koch, Georg. Archaeological Live Interpretations, Docu-Soaps and Themed Walks: Similarities and Differences //EXARC Journal. 2014. Issue 2. https://exarc.net/issue-2014-2/int/archaeological-live-interpretations-docu-soaps-and-themedwalks-similarities-and-differences

102. Wright J.L. Bodies of Evidence: The Rhetoric of Simulated History. PhD diss., University of Texas. 2007.

103.Baudrillard, J. Simulacra and Simulation. Michigan. 1994.

104.Turner, Victor W, Bruner, Edward M. The Anthropology of Experience. University of Illinois Press. 1986.

105.Teunissen Martine. Representation of the Past in Public Spheres. Experiencing the Past: the Reconstruction and Recreation of History at Colonial Williamsburg. Brave New Books. 2017.

106. Wenzel Geissler P, Ann H Kelly. Field station as stage: Re-enacting scientific work and life in Amani, Tanzania // Social Studies of Science 2016. Vol. 46(6). Pp. 912-937.

107. Pine, J., Gilmore, J. The experience economy: work is theatre \& every business a stage. Harvard Business Press. 1999.

108. Sundbo, J. Handbook on the Experience Economy. Edward Elgar Publishing. 2013. 